\title{
Long-term prognosis of commercially sexually exploited youth in Turkey: Brief report
}

\author{
Bengi SEMERCi, ${ }^{1}$ Sarper TAŞKIRAN, ${ }^{2}$ Ali Evren TUFAN, ${ }^{3}$ Işın ŞANLI ${ }^{1}$
}

\begin{abstract}
Objective: Factors contribute to commercial sexual exploitation of youth (CSEY) and a variety of physical and psychological consequences of CSEY were previously discussed in the literature. The aim of the current study was to determine the long term prognosis of a sample of CSEY in Turkey. Methods: A sample of 108 CSEY (all females) with a mean age of 16.7 \pm 2.7 (range: 9-22) years living in a specialized center for protection against perpetrators were examined in terms of their sociodemographic variables, previous abuse history, family history and current psychopathology. Identified cases were referred for psychiatric evaluation. We obtained follow-up data 11 years after initial contact from this cohort (mean age 25.9 \pm 2.6 at time of follow-up) with the subjects and received information regarding their current functioning. Results: Follow up data revealed that recommendations during psychiatric follow up could not be acted upon. $71.4 \%$ of the initial sample $(n=76)$ could be reached via direct or indirect contacts. We found that good/ superior functioning was very rare and that one- third of the sample that could be reached still was being sexually exploited. Important considerations derived from the results were discussed in the current article. (Anatolian Journal of Psychiatry 2017; 18(2):184-187)
\end{abstract}

Keywords: child abuse, sexual abuse, adolescence, prostitution, residential treatment, commercial sexual exploitation of youth

\section{ÖZET}

\section{Türkiye'de ticari cinsel sömürüye maruz kalan gençlerin uzun dönemli prognozu: Kısa rapor}

Amaç: Gençlerin ticari cinsel sömürüye uğramalarında rol oynayan etkenler ve sonucunda ortaya çıkan çeşitli fiziksel ve ruhsal sonuçlar şimdiye kadar yapılan araştırmalara konu olmuştur. Bu çalışmanın amacı, Türkiye'de ticari cinsel sömürüye uğramış olan gençlerin uzun dönemli prognozunu incelemektir. Yöntem: Araştırmanın örneklemini yaş ortalaması 16.7 \pm 2.7 (aralık: 9-22) olan ticari cinsel sömürüye uğramış ve bir koruma merkezine yerleştirilmiş 108 genç kız oluşturmaktadır. Bu gençler sosyodemografik değişkenler, geçmiş istismar öyküsü, aile öyküsü ve psikopatolojik durumları açısından incelenmiştir. Psikopatolojik olarak gerekli görülen olgular psikiyatrik izleme için yönlendirilmiştir. Gençlerle ilk karşılaşmadan 11 yıl sonra izleme için iletişim sağlanmış (izlemde ortalama yaş

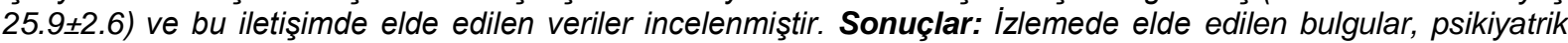
izleme için yapılan yönlendirmenin yerine getirilemediğini göstermiştir. On bir yıl sonra yapılan izlemede, ilk iletişimle ulaşılan örneklemin \%71.4'üne doğrudan veya dolaylı yollarla ulaşmak olası olmamıştır. Bulgular, gençlerde üst düzeyde/iyi işlevselliğe sahip olma oranının çok düşük olduğunu ve örneklemde ulaşılabilen grubun üçte birinin halen cinsel sömürüye uğradığını göstermiştir. Elde edilen bulgulardan edinilen önemli çıkarımlar bu makalede tartışılmaktadır. (Anadolu Psikiyatri Derg 2017; 18(2):184-187)

Anahtar sözcükler: Çocuk istismarı, cinsel istismar, ergenlik, fuhuş, koruma evi, gençlerin ticari cinsel sömürüsü

\footnotetext{
${ }^{1}$ Bengi Semerci Institute, İstanbul, Turkey

${ }^{2}$ Koç University School of Medicine.

${ }^{3}$ Abant Izzet Baysal University, Health Center, Bolu, Turkey

Correspondence address I Yazışma adresi

Dr. Sarper TAŞKIRAN, Koç University School of Medicine, İstanbul, Turkey

E-mail: ataskiran@ku.edu.tr

Geliş tarihi: 14.03.2016, Kabul tarihi: 23.05.2016, doi: 10.5455/apd.221914

Anatolian Journal of Psychiatry 2017; 18(2):184-187
} 


\section{INTRODUCTION}

Commercial sexual exploitation of youth (CSEY) defines a commercial transaction involving the sexual exploitation of a minor (i.e., prostitution, pornography or trafficking for sexual purposes; via coercion or violence) or offering sexual services of children for financial/ other remunerations. ${ }^{1-3}$ Youth from both genders may be victims of CSE, although prostitution of girls is more prevalent in most countries. ${ }^{3}$ The United Nations Children's Fund (UNICEF) and the United Nations Population Fund (UNFPA) both estimate prevalence of CSEY as 2 million/year. ${ }^{3}$ There is more robust data on prevalence of CSEY in developed countries while data from developing countries such as Turkey is limited. ${ }^{1-4}$

Available data suggest that poverty, physical and sexual abuse, inadequate parental supervision and substance use may contribute to CSEY and that those youth suffer physically (i.e., sexually transmitted diseases, physical trauma, unwanted pregnancies etc.) and psychologically (i.e., depression, dissociation, substance use disorders, post-traumatic stress disorder) as a consequence..$^{1-3}$

A major limitation of most of those studies is their cross-sectional nature and relatively little is known about long-term prognosis of CSEY, especially from developing countries. ${ }^{4}$ Accordingly, further studies are required to determine factors related with CSEY in diverse populations and their long- term prognosis. Therefore, the aim of this study was to determine the long term (i.e. eleven years) prognosis of a sample of CSEY reported previously. ${ }^{4}$

\section{METHODS}

\section{Study center and sampling}

The original sample included CSEY identified by Child Protection Services and housed at a specific protection center located in Taksim, Istanbul. CSEY identified in the year of 2003 in Istanbul were referred to the center for housing and protection. The clinicians working at this center provided initial psychiatric evaluation and referred identified cases for psychiatric followup. Here, follow-up data eleven years after referral of the original sample is presented.

\section{Sociodemographic and clinical features of the initial sample}

The initial sample consisted of 108 CSEY (all females) with a mean age of $16.7 \pm 2.7$ years (range: $9-22$ ). To briefly recapitulate, $25.0 \%$ of the initial sample had no formal education and a further $43.0 \%$ were barely literate. More than one-thirds $(36.0 \%)$ were previous victims of sexual abuse, mostly in their families. A majority (73.2\%) reported previous physical abuse in their families. $10.2 \%$ of the initial sample were forced into marriage by their families with $9.3 \%$ receiving official status. One fourth had legal problems. As for their family histories, one third were offspring of broken families and $21.0 \%$ had a family history of criminal convictions. Twentyone per cent reported that one or more of their family members (mostly sisters/mothers) also engaged in prostitution. The rate of psychopathology in the initial sample was $30.0 \%(\geq 1$ disorder according to DSM-IV-TR criteria, with high comorbidity). Most common disorders were nicotine abuse/dependence (85.0\%), alcoholsubstance abuse/dependence (43.0\%) and conduct disorder (20.0\%). Rates for other psychopathologies were as follows; attention-deficit/ hyperactivity disorder (15.0\%), intellectual disability (mental retardation) (10.0\%), major depressive disorder (10.0\%) and anxiety disorders (8.0\%).

The clinical staff evaluating the original sample of CSEY strongly recommended affiliation with a specialized child and adolescent psychiatrist to provide evaluation and follow-up and failing that they also urged a cadre of stable clinicians to facilitate therapeutic relationships but it was learned later that those recommendations could not be acted upon.

The participants who were reached via phone interview ( $N=76$ ) were asked to complete Contentment with Life Satisfaction Scale (CLAS). ${ }^{5}$ We used the Turkish version which has been translated and validated for reliability. ${ }^{6}$ During the phone interview, information regarding living situation, family structure, ongoing abuse, domestic violence, financial situation, educational status was obtained.

\section{Ethics and statistics}

The study procedures were conducted in accordance with the Declaration of Helsinki, Good Clinical Practices and local law and regulations. Informed consent was procured from the study participants and their legal guardians before enrollment and the study procedures were approved by the institutional review boards of Ministry of Family and Social Policies. The sociodemographic and clinical features of the CSEY were evaluated with descriptive statistics.

Anadolu Psikiyatri Derg 2017; 18(2):184-187 


\section{RESULTS}

A follow-up contact with the original staff after eleven years found that recommendations for psychiatric follow-up could not be acted upon due to budgetary concerns and that CSEY were referred to various state hospitals with frequent changes in clinicians. As a result, CSEY usually refused attending their planned visits citing lack of a trusting, therapeutic relationship. Eighty-one per cent of the initial sample ran away from the center at various times and came back later, either voluntarily or by the help of police. After a year of remaining in operation, the center was closed down by the responsible authorities citing budgetary concerns and low functionality and the remaining youth were transferred to other, non-specific protection centers.

As for the CSEY themselves, 48.2\% $(n=52)$ could be reached directly via their official records. An additional 25 CSEY (23.2\%) were reached by indirect contacts. Therefore the final sample consisted of $71.4 \%$ of the initial sample $(n=76)$. Thirty per cent of this follow-up sample $(n=23)$ still engaged in prostitution. A minority were married for a time $(n=4,5.0 \%)$ but later separated/ divorced. All of those married were admitted for a time to safe homes due to domes- tic abuse by their partners. Two of the CSEY who were married had children but one had to give her child for adoption. One of the CSEY had reported psychiatric hospitalizations due to substance dependence and other psychopathologies. Good/ superior functioning was found only in $2.6 \%$ of the CSEY $(n=2)$. One of those was academically gifted and received financial and emotional support from a volunteer group all through her education, finishing college and working successfully thereafter. She also received free psychiatric follow-up and therapy from a volunteer child and adolescent psychiatrist. The other was a victim in high-profile legal dispute covered by the media and received special attention as a result. Her education and psychiatric care was funded by an NGO.

The total CLAS scores of participants are given in Figure 1. Initial scores report positive measures, higher scores indicate higher life satisfaction, whereas latter scores are negatively coded; thus, higher scores indicate poor life satisfaction. There were no significant differences between divorced, actively prostituting and other groups in terms of CLAS scores. Participants who continued psychiatric follow-up had significantly better life satisfaction. $(p<0.05)$

\section{Figure 1.}

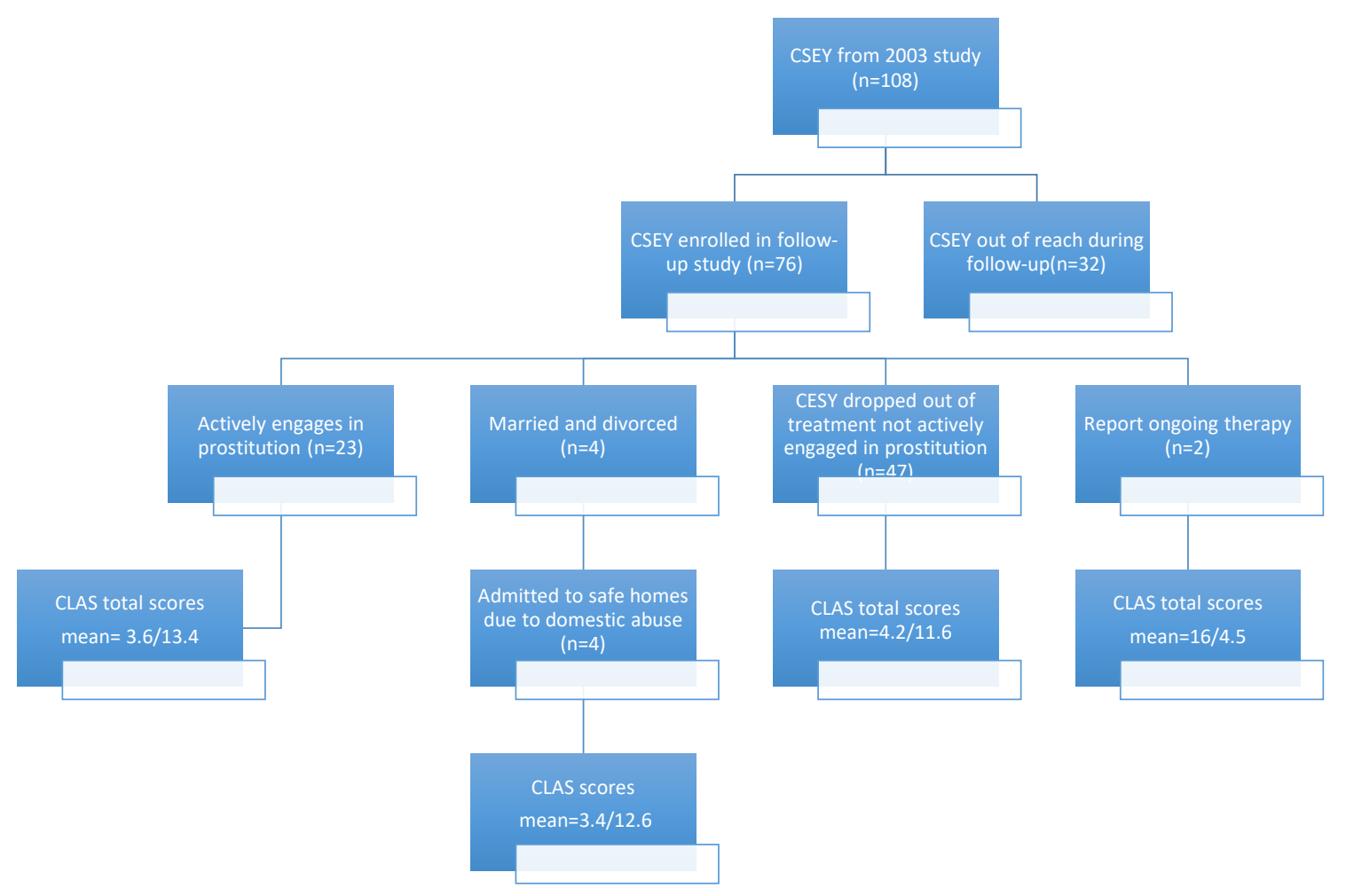

Anatolian Journal of Psychiatry 2017; 18(2):184-187 


\section{DISCUSSION AND CONCLUSIONS}

In a study that aimed to determine the long term (i.e. eleven years) prognosis of a sample of CSEY reported previously from Turkey we found that only good/ superior functioning was rare and that one-third of the sample that could be reached still engaged actively in prostitution. The experiment of a specified protection and housing center for CSEY identified by the child protection services could not be maintained citing budgetary concerns and reduced efficiency. Most of the initial sample of CSEY ran away from the center at various times and refused attending their planned visits citing lack of a trusting relationship.

The results of this follow-up study point to several important considerations; one of which is the necessity of continuing formal education in CSEY. Another important prognostic factor seems to be individualized psychiatric care provided by a stable, dedicated cadre of clinicians. ${ }^{7}$ Psychiatric care should be planned for the long term, not in context of brief panaceas. Establishing a stable connection between a therapist and the individual predicts good prognosis.

Our results should be evaluated in terms of their limitations; namely, a biased and limited sample, recruited from a dedicated center for CSEY and a high attrition rate. The follow-up sample was also not evaluated psychiatrically and our data suffer from limitations of all studies that depend on self-reports. Regardless of limitations, the results emphasize the importance of providing continuous psychiatric care and educational support to CSEY. In order to do that, child psychiatrists should be proactive and broaden their patient populations providing outreach to disadvantaged youth. Barriers to accessing and receiving care among CSEY also should be addressed.

\section{REFERENCES}

1. Estes RJ, Weiner NA. The Commercial Sexual Exploitation of Children in the U.S., Canada and Mexico. Full Report of the U.S. National Study (09.18.2001; Revised 02.20.2002). [Accessed on 06.29.2015 at http://abolitionistmom.org/wpcontent/uploads/2014/05/Complete_CSEC_Oestes -weiner.pdf]

2. Gragg F, Petta I, Bernstein H, Eisen K, Quinn L. New York Prevalence Study of Commercially Sexually Exploited Children: Final Report. (04.18.2007). (Accessed on 06.10.2015 at http://www.ofcs.State.ny.us/main/reports/csec2007.pdf)

3. http://yapi.org/csec-and-child-trafficking/ (Accessed on 06.16.2015)

4. Semerci B, Soyer A, Cokgizkin A. Child prostitution in Turkey. $13^{\text {th }}$ International Congress of the European Society of Child and Adolescent Psychiatry
(ESCAP): Bridging the Gaps, 25-29 th August 2007, Florence, Italy.

5. Lavallee LF, Hatch PM, Michalos A C, McKinley T.. Development of the contentment with life assessment scale (CLAS): Using daily life experiences to verify levels of self-reported life satisfaction. Social Indicators Research 2007; 83(2):201-244.

6. Akin A, Yalniz A. Yaşam Memnuniyeti Ölçeği (YMÖ) Türkçe Formu: Geçerlik ve güvenirlik çalişmasi. Turkish Version of Contentment with Life Scale (CLAS): the Study of Validity and Reliability Electronic Journal of Social Sciences 2015; 14(54):95102.

7. Ijadi-Maghsoodi R, Todd EJ, Bath EPJ. Commercial sexual exploitation on children and the role of the child psychiatrist. J Am Acad Child Adolesc Psychiatr 2014; 53:825-829. 